\title{
An Oligomannuronic Acid-Sialic Acid Conjugate Capable of Inhibiting $A \beta 42$ Aggregation and Alleviating the Inflammatory Response of BV-2 Microglia
}

\author{
Jianrong $W u^{1, * \mathbb{D}}$, Miaosen $W u^{1}$, Hongtao Zhang ${ }^{1}$, Xiaobei Zhan ${ }^{1}$ and Nian $W u^{2}$ \\ 1 Key Laboratory of Carbohydrate Chemistry and Biotechnology, Ministry of Education, \\ School of Biotechnology, Jiangnan University, Wuxi 214122, China; wu1094482998@foxmail.com (M.W.); \\ htzhang@jiangnan.edu.cn (H.Z.); xbzhan@jiangnan.edu.cn (X.Z.) \\ 2 Division of Histology and Embryology, International Joint Laboratory for Embryonic Development and \\ Prenatal Medicine, Medical College, Jinan University, Guangzhou 510632, China; nian5999@sina.com \\ * Correspondence: kinowu@jiangnan.edu.cn; Tel.: +86-510-85918299
}

check for updates

Citation: Wu, J.; Wu, M.; Zhang, H.; Zhan, X.; Wu, N. An

Oligomannuronic Acid-Sialic Acid Conjugate Capable of Inhibiting A $\beta 42$ Aggregation and Alleviating the Inflammatory Response of BV-2 Microglia. Int. J. Mol. Sci. 2021, 22, 12338. https://doi.org/10.3390/ ijms222212338

Academic Editor: Isidro Ferrer

Received: 23 October 2021

Accepted: 12 November 2021

Published: 15 November 2021

Publisher's Note: MDPI stays neutral with regard to jurisdictional claims in published maps and institutional affiliations.

Copyright: (c) 2021 by the authors. Licensee MDPI, Basel, Switzerland. This article is an open access article distributed under the terms and conditions of the Creative Commons Attribution (CC BY) license (https:// creativecommons.org/licenses/by/ $4.0 /)$.

\begin{abstract}
Oligomannuronic acid (MOS) from seaweed has antioxidant and anti-inflammatory activities. In this study, MOS was activated at the terminal to obtain three different graft complexes modified with sialic acid moiety (MOS-Sia). The results show that MOS-Sia addition can reduce the $\beta$-structure formation of $A \beta 42$, and the binding effect of MOS-Sia3 is more obvious. MOS-Sia conjugates also have a better complexing effect with $\mathrm{Ca}^{2+}$ while reducing the formation of $\mathrm{A} \beta 42$ oligomers in solutions. MOS-Sia3 $(25-50 \mu \mathrm{g} / \mathrm{mL})$ can effectively inhibit the activation state of BV-2 cells stimulated by A $\beta 42$, whereas a higher dose of MOS-Sia3 $(>50 \mu \mathrm{g} / \mathrm{mL})$ can inhibit the proliferation of BV-2 cells to a certain extent. A lower dose of MOS-Sia3 can also inhibit the expression of IL- $1 \beta$, IL-6, TNF- $\alpha$, and other proinflammatory factors in BV-2 cells induced by A $\beta 42$ activation. In the future, the MOS-Sia3 conjugate can be used to treat Alzheimer's disease.
\end{abstract}

Keywords: oligomannuronic acid; sialic acid; Alzheimer's disease; $\beta$-amyloid; microglia

\section{Introduction}

Alzheimer's disease (AD) is a common progressive neurodegenerative disease that is clinically characterized by cognitive impairments. According to data released by the International Alzheimer's Association, one patient with dementia occurs worldwide every $3.2 \mathrm{~s}$ [1]. The pathogenesis of AD is complex and inconclusive. The pathological features of AD patients primarily show senile plaques formed by the aggregation of $\beta$-amyloid and intracellular neurofibrillary tangles caused by the phosphorylation of tau protein. However, all of the already established treatments that are approved today try to counterbalance the neurotransmitter imbalance of the disease. For example, acetylocholinesterase inhibitors include Donepezil, Galantamine, and Rivastigmine. Another therapeutic agent approved for moderate to severe $\mathrm{AD}$ is the noncompetitive $\mathrm{N}$-methyld-aspartate (NMDA) receptor antagonist Memantine [2]. No new drug has been approved by FDA for AD since 2003 despite many long and expensive trials, and more than 200 research projects in the last decade have failed or have been abandoned [3]. The recent approval request to the FDA for the monoclonal antibody Aducanumab (Biogen) is also controversial [4]. Following these controversies, the FDA did not grant full approval of the Aducanumab medication.

Sialic acid is a type of 9-C ketonic acid extensively present in the sugar-chain terminal of cellular glycoproteins, glycolipids, and small RNA [5]. Sialic acid plays an important role in neural development, cell recognition, tumor migration, and other biological processes. Numerous sialylated glycans exist in human brain tissues. In neonatal brains, sialic acid primarily exists in the form of polysialic acid (PSA), in neural-cell adhesion molecule, and PSA vanishes after adulthood. Given the strong negativity and non-immunogenicity of PSA, several groups have attempted to construct a sialic acid complex for AD treatment. 
For instance, a polyamidoamine dendrimer grafted with sialic acid was synthesized to mimic the PSA structure in the neonatal brain, and this dendrimer complex could alleviate $\beta$-amyloid-induced neurotoxicity [6]. Furthermore, three different sialylated oligosaccharides (DSLNT, LNNT, and 3SL) were photo-crosslinked to obtain PSA analogs. Results show that only the polymer from DSLNT can reduce the neurotoxicity of $A \beta$, and a higher dose of cross-linked DSLNT can attenuate the toxicity from A $\beta$ [7]. In microglia, Siglec 3 (CD33) expression is found to be positively correlated with $A \beta$ plaque burden, and CD33 inactivation by synthetic analogs of sialic acid could reduces the insoluble A $\beta 42$ levels in APPSwe/PS1 $\triangle \mathrm{E} 9$ mouse brain [8]. A novel nanoparticle embellished with oligo PSA (2-3 DP) could reportedly interact with Siglec-E and inhibit the activation of microglia and inflammatory response [9]. These findings demonstrate that sialic acid containing polymer is a potential PSA analog for attenuating $A \beta$ toxicity relative to the human brain. Given the instability of naturally occurring PSA, a novel structural design of PSA analog is urgent.

Oligomannuronic acid (MOS), a $\beta$-D-mannuronic acid polymer linked by $\beta-(1,4)$ glycosidic bonds, is prepared from the degradation and separation of alginate from seaweed. MOS shows high bioactivity in immune regulation, as well as antitumor, antioxidation, and anti-inflammatory effects $[10,11]$. MOS can also increase SOD in rat brain tissues, thereby inhibiting brain cell damage caused by oxidative stress, protecting neurons and improving rat cognitive ability [12]. Moreover, MOS can activate the neurotrophic factors of glial cells in a clinical trial, thereby improving neuroprotective function [13]. MOS has also been tested in the prevention and treatment of neurodegenerative diseases. One of its derivatives, GV-971 (an oxidation product at the reducing terminal of MOS), shows an important breakthrough in AD treatment and is approved by CFDA as a cure for patients with mild to moderate Alzheimer's disease [14]. GV-971 is found to remodel gut microbiota, reduce the accumulation of peripheral metabolites phenylalanine/isoleucine, and reduce neuroinflammation in the brain, resulting in improved cognitive impairment. However, the body adsorption rate of GV-971 through oral administration (900 mg ever day) is very low, and only six-thousandth of it enters the brain.

Reducing $A \beta$-plaque burden is one strategy for treating AD. Several anti-amyloid aggregation agents such as the oral agent scyllo-inositol and the peptidomimetics KLVFF were developed $[15,16]$. In addition, abnormal accumulation or dyshomeostasis of metal ions such as iron, copper, and zinc has been associated with the pathophysiology of AD. Some metal chelating agents, such as Deferiprone and PBT2 (a metal protein-attenuating compound), were synthesized and studied in phase 2 trials $[17,18]$. In the current study, based on the role of sialic acid in biological recognition and the excellent biocompatibility of mannuronic acid, an electronegative oligo mannuronic acid-sialic acid conjugate (MOS-Sia) was synthesized by chemical methods to yield an oligo PSA mimic analog. The interactions of MOS-Sia with A $\beta 42$ and metal ions, as well as its effect on reducing the neurotoxicity of $A \beta$ on microglia, were investigated. The use of MOS-Sia is a potential alternative method of treating cognitive impairment.

\section{Results}

\subsection{Synthesis and Characterization of MOS-Sia}

MOS-Sia of different structures was synthesized according to Scheme 1. An amino group was introduced into the reducing terminal of MOS (3-5 DP) to produce MOS$\mathrm{NH}_{2}$ through reductive amination (100\% yield). MOS- $\mathrm{NH}_{2}$ was then reacted with $\mathrm{N}$ acetylneuraminic acid directly through reductive amination, and the obtained conjugate was denoted as MOS-Sia1, with a conversion yield of $75.6 \%( \pm 0.52)$. In another trial, MOS- $\mathrm{NH}_{2}$ was reacted with N-acetylneuraminic acid under the catalysis of EDC through amidation. The resulting product was denoted as MOS-Sia2, with a conversion yield of $82.7 \%( \pm 0.63)$. In the process of alcohol precipitation and dialysis for product purification, MOS-Sia1 and MOS-Sia2 were partially degraded, resulting in decreased yield. In addition, $\mathrm{N}$-acetylneuraminic was initially protected by methyl ester acetylation to gen- 
erate 1-Me-Ac5SiaNAc, with a yield of 75.6\% ( \pm 0.38$)$. MOS $(3-5 \mathrm{DP})$ was reacted with mercaptoethylamine to introduce sulfhydryl at the reducing end of oligo mannuronic acid to obtain MOS-SH (yield of $92.5 \% \pm 0.35 \%$ ). Under the catalysis of boron trifluoride ether $(\mathrm{BF} 3 \bullet \mathrm{Et} 2 \mathrm{O}), 1-\mathrm{Me}-\mathrm{Ac} 5 \mathrm{SiaNAc}$ was reacted with MOS-SH to produce MOS-Sia3, with a yield of $89.2 \%( \pm 0.42)$.

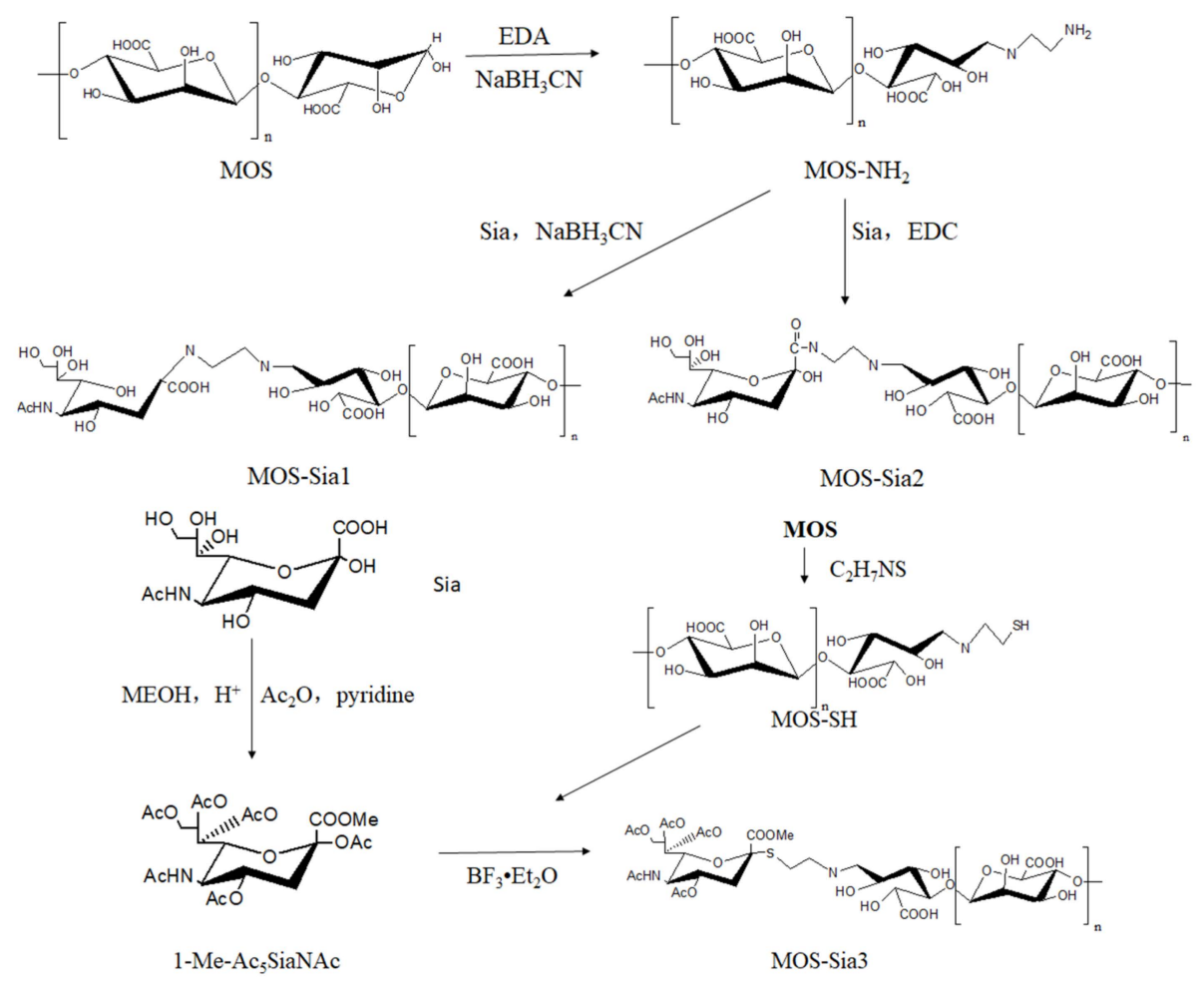

Scheme 1. Preparation of MOS-Sia by reductive amination, amidation, and thiol condensation.

The MOS-Sia's were characterized by LC-MS, and the results are shown in Figure 1. Regarding MOS-Sia1, the peaks at $m / z 718.53,916.55$, and 1087.55 corresponded to aminated di-mannuronic acid $\left.\mathrm{M}_{1}+\mathrm{CH}_{2}-\mathrm{H}\right]^{-}$, aminated tri-mannuronic acid $\left[\mathrm{M}_{1}+\mathrm{Na}+\mathrm{CH}_{2}-\mathrm{H}\right]^{-}$, and aminated tetra-mannuronic acid $\left[\mathrm{M}_{1}+\mathrm{Na}-\mathrm{H}\right]^{-}$, respectively. With respect to the mass spectrum of MOS-Sia2, $m / z$ at 702.92, 899.30, 1052.44, and 1229.17 were from amidated dimannuronic acid $\left[\mathrm{M}_{2}-\mathrm{H}\right]^{-}$, amidated tri-mannuronic acid $\left[\mathrm{M}_{2}+\mathrm{Na}-2 \mathrm{H}\right]^{2-}$ and amidated tetra-mannuronic acid $\left[\mathrm{M}_{2}-3 \mathrm{H}\right]^{3-}$, and amidated penta-mannuronic acid $\left[\mathrm{M}_{2}-2 \mathrm{H}\right]^{2-}$, respectively. Mass spectrometry analysis of MOS-Sia3 showed that the peaks at $m / z$ 1077.2, 1253.64, and 1276.08 corresponded to $-\mathrm{SH}$ linked tris-mannuronic acid $[\mathrm{M} 3-\mathrm{H}]^{-},-\mathrm{SH}$ linked tetra-mannuronic acid $[\mathrm{M} 3-\mathrm{H}]^{-}$, and $-\mathrm{SH}$ linked tetra-mannuronic acid sodium $[\mathrm{M} 3+\mathrm{Na}-\mathrm{H}]^{-}$, respectively. Overall, three MOS-Sias were successfully synthesized.

\subsection{Effect of MOS-Sia on the Sedimentation of $A \beta 42$}

Previous studies have shown that the dynamic imbalance of metal ions such as $\mathrm{Ca}^{2+}$, $\mathrm{Zn}^{2+}$, and $\mathrm{Cu}^{2+}$ could trigger $\mathrm{A} \beta$ aggregation in the brain of $\mathrm{AD}$ patients, and polysialic acid presence in the brain could reduce cytotoxicity from metal imbalance through chelation [19]. Accordingly, we determined whether MOS-Sia reduced A $\beta$ aggregation and precipitation caused by metal ions, as shown in Figure 2. $\mathrm{Ca}^{2+}$ had little effect on the aggregation and precipitation of $\mathrm{A} \beta 42$ than compared with $\mathrm{Cu}^{2+}$ and $\mathrm{Zn}^{2}$. The addition of MOS-Sia1, MOS-Sia2, and Sia reduced soluble A $\beta 42$ content significantly in the $\mathrm{Ca}^{2+}$ group. However, the addition of MOS-Sia3 could even increase the soluble A $\beta 42$ content compared with the control. In the presence of $\mathrm{Cu}^{2+}$ and $\mathrm{Zn}^{2+}$, soluble $\mathrm{A} \beta$ was greatly reduced, indicating that these two metal ions were liable to cause $A \beta 42$ to aggregate and precipitate. After adding MOS-Sia or monomer sialic acid, soluble $A \beta 42$ in the supernatant increased in 
the $\mathrm{Cu}^{2+} / \mathrm{Zn}^{2}$ groups. Among them, the effect of MOS-Sia3 was the most obvious. The electronegativity of and stereoselectivity of MOS-Sia3 may favor its interaction with A $\beta 42$ and inhibit $A \beta 42$ aggregation. The complete structure of sialic acid was destroyed during the synthesis of MOS-Sia1 and MOS-Sia2, proving the importance of the completed terminal sialic acid structure for its interaction with $\mathrm{A} \beta 42$ and metal ions. Thus, the electronegative block-sugar complex with a complete sialic acid structure played an important role in stabilizing $A \beta 42$ structure.
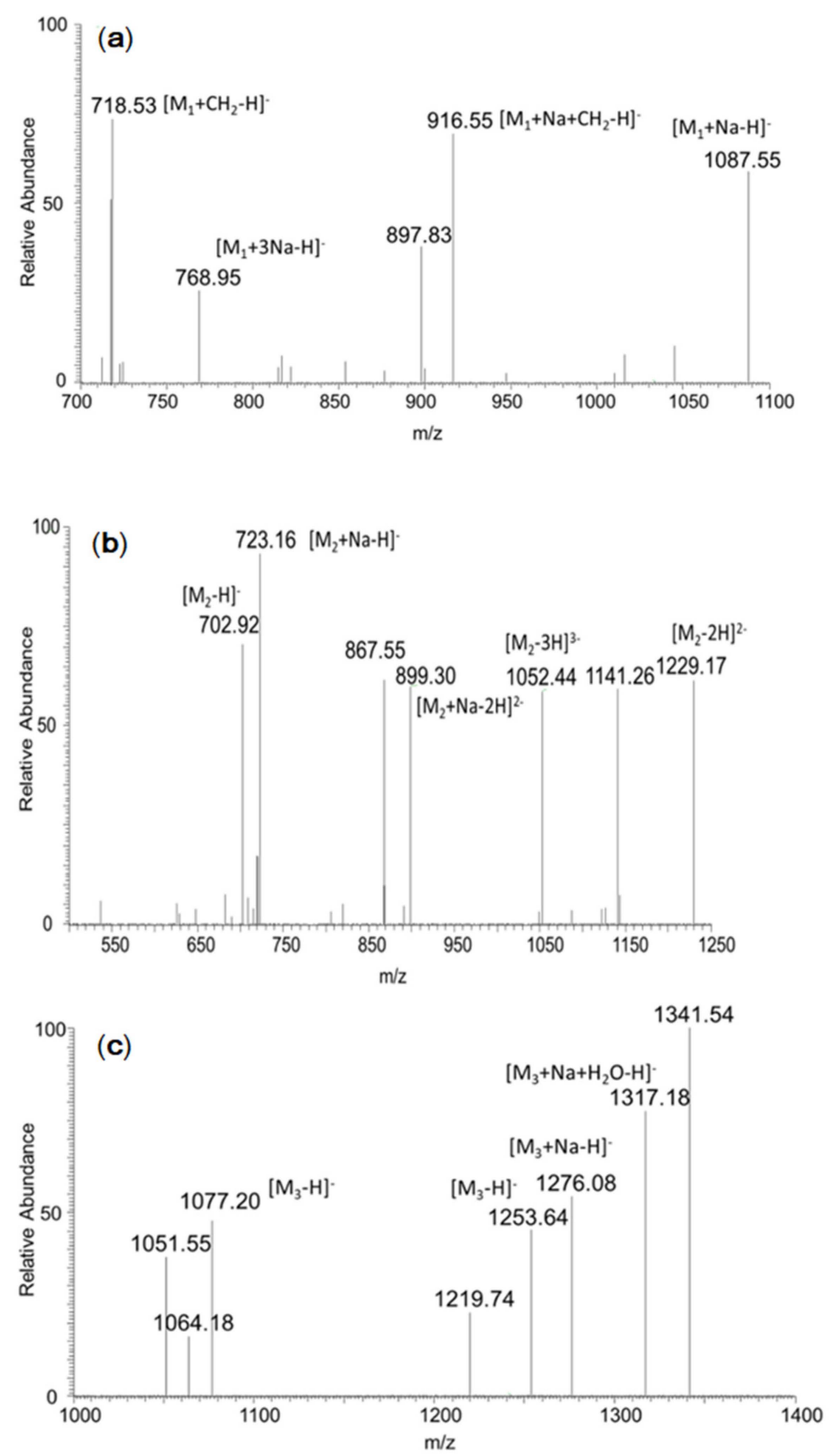

Figure 1. MS spectra of MOS-Sia. (a) MOS-Sia1, (b) MOS-Sia2, and (c) MOS-Sia3. 


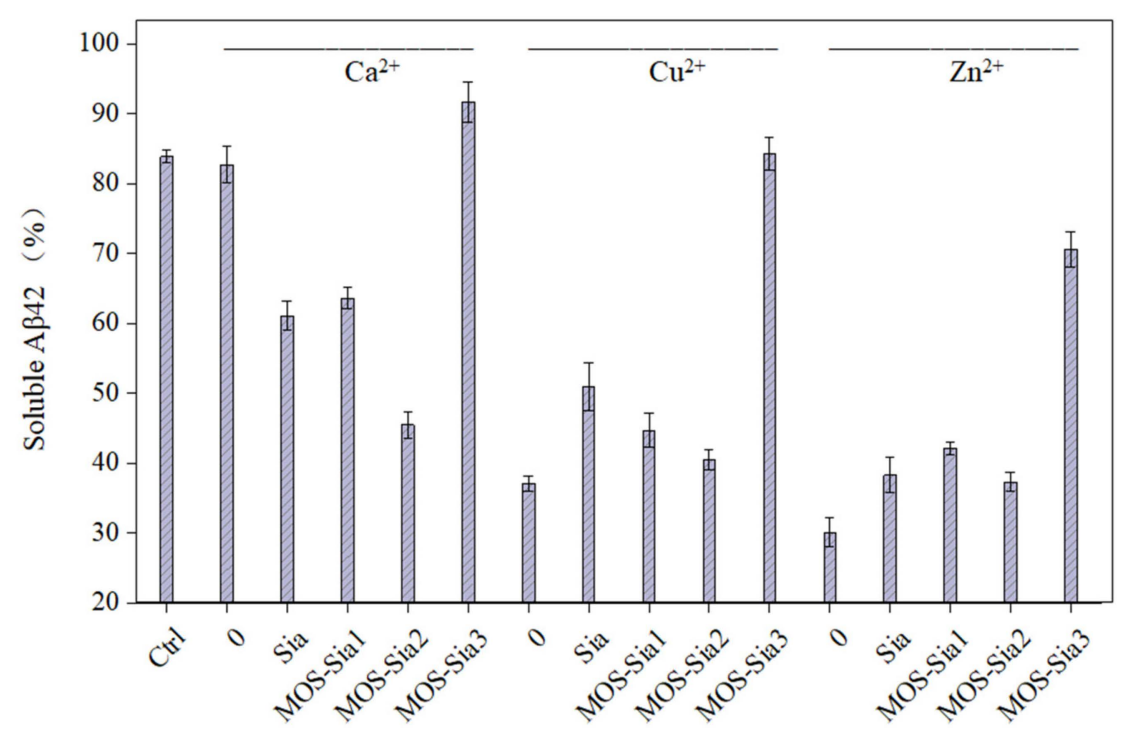

Figure 2. Residual soluble $\mathrm{A} \beta$ in supernatant after interaction with MOS-Sia, metal ion, and $\mathrm{A} \beta 42$. Note: Molar ratio of A $\beta 42$ to metal ion was set as 1:1, with incubation for $24 \mathrm{~h}$. Data are shown as the mean \pm SD of triplicates.

\subsection{Thioflavin $T$ (ThT) Analysis of Interaction between $A \beta 42$ and MOS-Sia}

ThT is a benzoprothiazole dye that specifically binds to $A \beta$ to increase fluorescence with specific excitation wavelength at $450 \mathrm{~nm}$ and maximum emission wavelength at $482 \mathrm{~nm}$. Amyloid is rich in $\beta$-sheet structure and can specifically bind to ThT, and the presence of ThT does not affect the kinetic process of $A \beta$ aggregation [20]. As shown in Figure 3, all three MOS-Sia had a certain degree of inhibitory effect on A $\beta 42$. After incubation for $32 \mathrm{~h}$, the fluorescence intensity leveled off. MOS-Sia1 and MOS-Sia2 inhibited $50 \%$ of ThT fluorescence intensity, whereas MOS-Sia3 inhibited 70\% of ThT fluorescence intensity. This finding proved decreased fibril formation from A $\beta 42$ aggregation in the presence of MOS-Sia3.

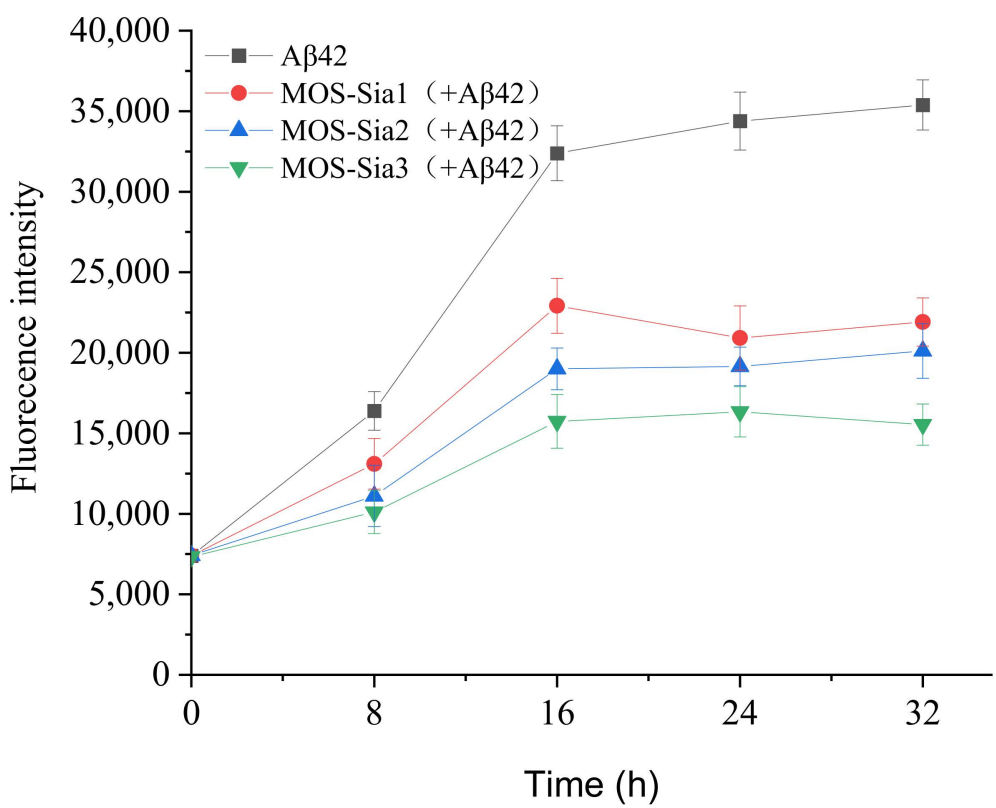

Figure 3. Fluorescence detection of the effect of MOS-Sia on A $\beta 42$ aggregation by ThT staining. Data are shown as the mean $\pm \mathrm{SD}$ of triplicates. 


\subsection{Circular Dichroism (CD) Analysis of Interaction between A 42 and MOS-Sia3}

The structural change of A $\beta 42$ after interaction with MOS-Sia3 was assayed by $C D$, and the results are shown in Figure 4. A broad and weak negative peak at $219-228 \mathrm{~nm}$ and a positive polarization peak at 200-208 nm were observed for $A \beta 42$ after incubation for $24 \mathrm{~h}$, indicating dominant $\beta$ sheets and fibril formation with increased molecular weight. After mixing with MOS, the negative peaks at 206-208 $\mathrm{nm}$ and the positive peaks at 200-202 and $215-223 \mathrm{~nm}$ showed that irregular curls and $\beta$-turns dominated. When $A \beta 42$ was incubated with MOS-Sia3, the absorption at around $192 \mathrm{~nm}$ increased, and the positive peak absorption at $206 \mathrm{~nm}$ was greatly reduced, indicating that MOS-Sia3 addition slowed down the formation of $\beta$-sheet structure and reduced the transformation of $A \beta 42$ to $\beta$-sheet structure. Moreover, double negative peaks at 207-210 and 226-228 nm, weak positive peaks at 192-194 nm, and wider positive peaks at $223 \mathrm{~nm}$ were observed, indicating a typical structure of $\alpha$-helix with irregular coils. Consequently, MOS-Sia3 showed better binding effects than MOS.

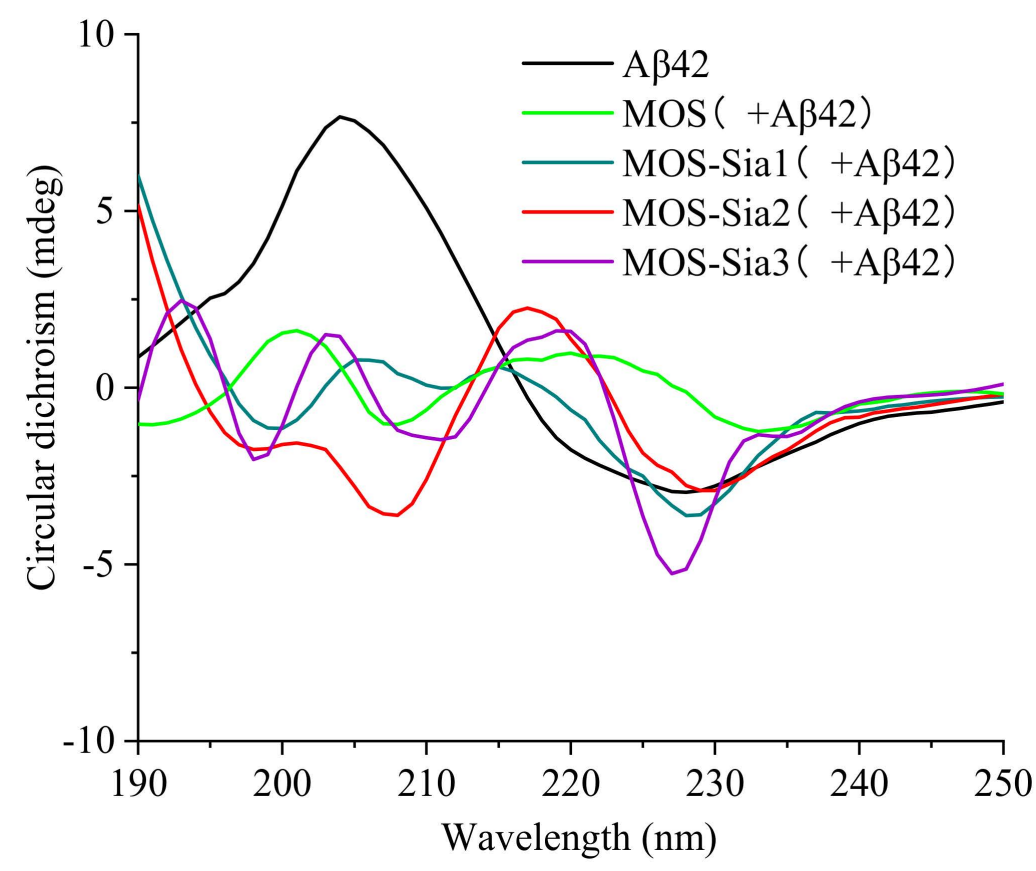

Figure 4. CD analysis of the interaction between MOS-Sia and A $\beta 42$.

\subsection{Effect of MOS-Sia3 on the Activity of BV-2 Cells Treated with A $\beta 42$}

Microglia plays a very important role in AD pathogenesis in which $A \beta$ stimulates the activation of microglia to initiate the phagocytosis of $A \beta$ for clearance. Regulating microglia activation is an important target for developing potential therapeutics for AD. The effect of MOS-Sia3 on the cell viability of BV-2 microglia was assayed by the MTT method, and the results are shown in Figure 5. Compared with the control group, the cell-survival rate reached $98.8 \%, 100.1 \%$, and $86.4 \%$ after $48 \mathrm{~h}$ of treatment with different concentrations of MOS-Sia3. At a lower concentrations of MOS-Sia3 $(25-50 \mu \mathrm{g} / \mathrm{mL}), \mathrm{BV}-2$ cell survival rate remained unaffected. If MOS-Sia3 $>100 \mu \mathrm{g} / \mathrm{mL}$, cell survival rate was inhibited. When A $\beta 42$ and MOS-Sia3 were used to treat BV-2 cells together, the cell viability of 25 and $50 \mu \mathrm{g} / \mathrm{mL}$ MOS-Sia3 groups slightly increased compared with the group without MOS-Sia3. When MOS-Sia3 > $100 \mu \mathrm{g} / \mathrm{mL}$, cell viability was also inhibited. The reason may be that the slightly acidic environment caused by the higher concentration of MOS-Sia3 was harmful to BV-2 cells. The morphology of BV-2 cells was observed after treating with MOS-Sia 3 and A $\beta 42$ for $48 \mathrm{~h}$, as shown in Figure 6. The normal morphology of BV-2 cells showed round and spindle-shaped adherent morphology. In the presence of $A \beta 42, B V-2$ cells had a small number of adherent cells. High $A \beta$ load is toxic and may cause microglial 
cell dysfunction due to excessive activation and may increase the risk for dementia [21]. Compared with the A $\beta 42$ model group, a lower concentration of MOS-Sia3 can inhibit the transformation of BV-2 cells into amoebic or long rod-like cells and can also reduce cell apoptosis in the presence of A $\beta 42$. When MOS-Sia3 was $>100 \mu \mathrm{g} / \mathrm{mL}$, MOS-Sia3 had a certain toxic effect on BV-2 and could not inhibit the release pro-inflammatory factors induced by $A \beta 42$ and even increase the secretion of IL- $1 \beta$ and TNF- $\alpha$. As a result, a high concentration MOS-Sia 3 and A $\beta 42$ can inhibit cell-morphology changes, but the proliferation of BV-2 cells was inhibited, which is consistent with the previous MTT assay.
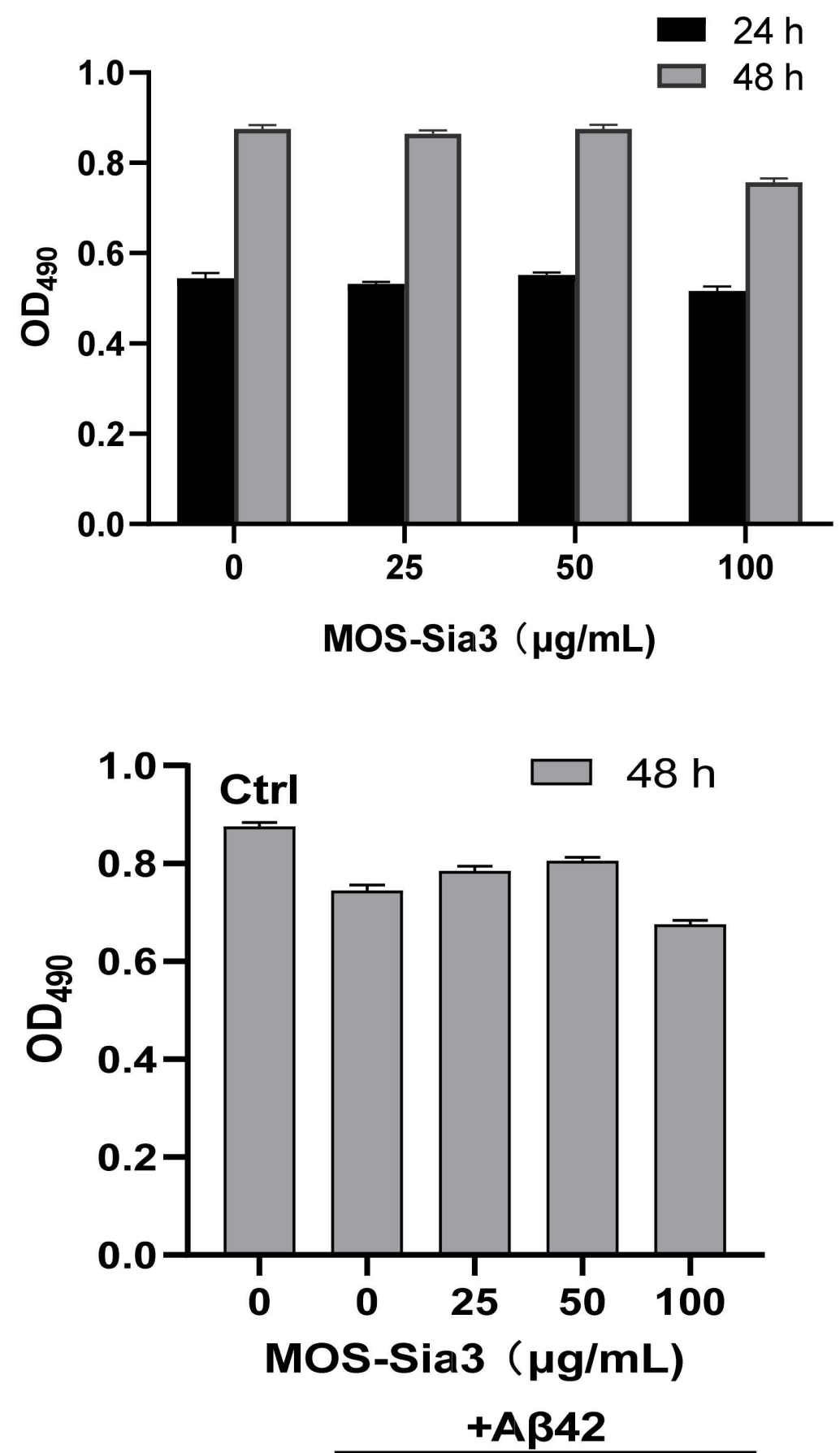

Figure 5. Effect of MOS-Sia3 on the cell growth of BV-2. Data are shown as the mean \pm SD of triplicates. 

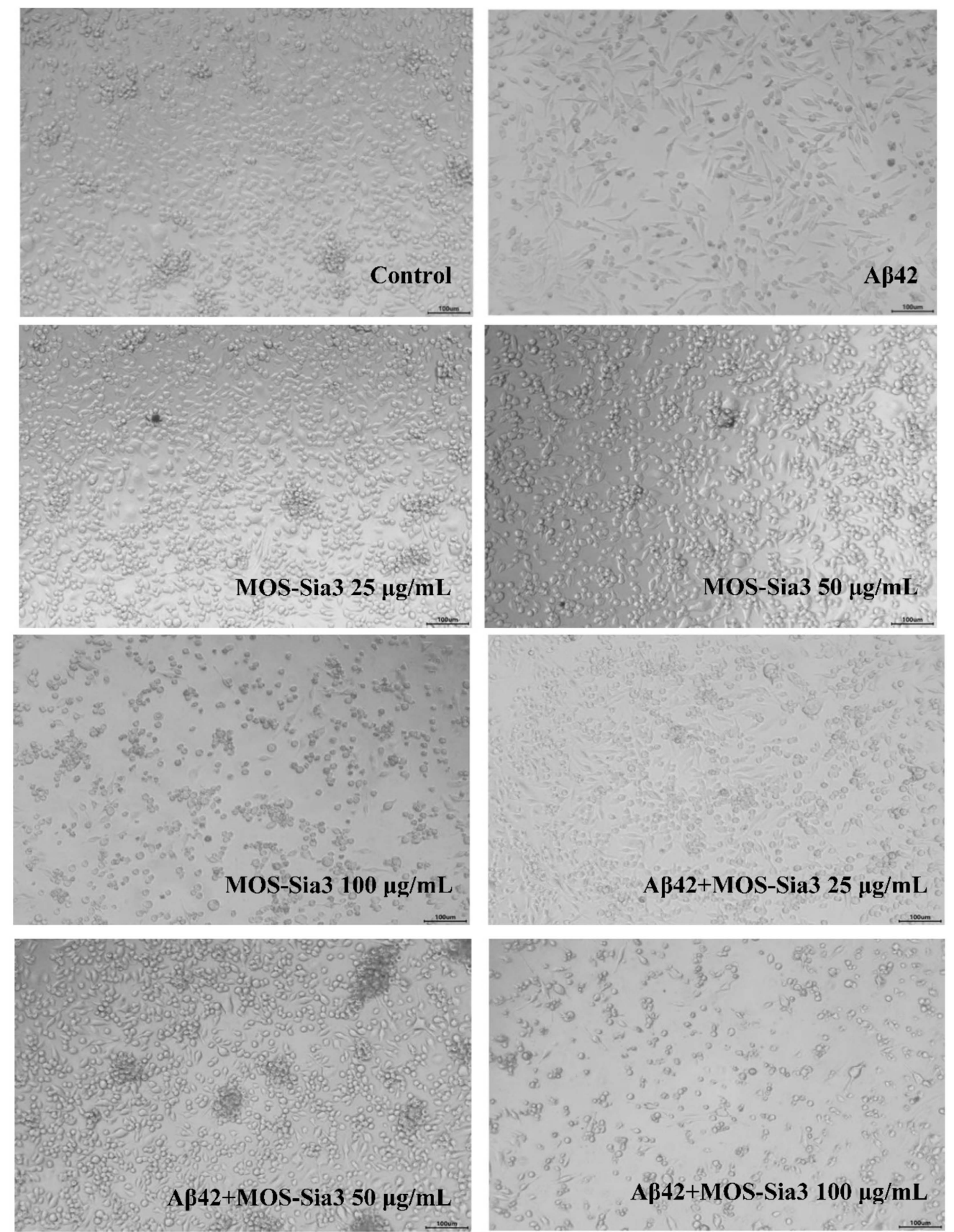

Figure 6. Morphological observation of BV-2 cells after administration with MOS-Sia3 and A $\beta 42$.

2.6. Effect of MOS-Sia3 on the Release of Inflammatory Factors in BV-2 Cells Induced by A 42

$A \beta$ can activate the phagocytic function of microglia. It also promotes the secretion of high levels of pro-inflammatory factors such as IL- $1 \beta$, IL- 6 , and TNF- $\alpha$, resulting in neuron dysfunction or death, thereby causing inflammation. The release of IL-1 $\beta$, IL-6, and TNF- $\alpha$ in BV-2 cells were measured by ELISA, and the results are shown in Figure 8 . Compared with the control group, the level of IL- $1 \beta$ secreted by BV-2 of the A $\beta 42$ model group significantly increased, and secretion reached $474.1 \pm 2.1 \mathrm{pg} / \mathrm{mL}$ at $48 \mathrm{~h}$. After administration with MOS-Sia3 25 and $50 \mu \mathrm{g} / \mathrm{mL}$ (the molar ratio of MOS-Sia3/A $\beta 42$ was 1:1.13 and 1:2.25, respectively), IL-1 $\beta$ production was significantly inhibited in BV-2 cells, indicating that MOS-Sia3 exerted a certain inhibitory effect on the inflammatory response produced by $A \beta 42$ and can reduce the degree of cell damage caused by $A \beta 42$. The addition of $25-50 \mu \mathrm{g} / \mathrm{mL}$ MOS-Sia3 alone had little effect on IL-1 $\beta$ secretion. However, in the case of $100 \mu \mathrm{g} / \mathrm{mL}$, the release of IL- $1 \beta$ was close to that of the A $\beta 42$ model group alone. In the 
presence of $100 \mu \mathrm{g} / \mathrm{mL}$ MOS-Sia3 and A $\beta 42$ (molar ratio of MOS-Sia3 $/ \mathrm{A} \beta 42=1: 4.52$ ), IL$1 \beta$ secretion further increased. With respect to IL- 6 , its secretion in the A $\beta 42$ model group significantly increased compared with that of the control group, and secretion reached $133.5 \pm 1.0 \mathrm{pg} / \mathrm{mL}$ at $48 \mathrm{~h}$. In the MOS-Sia3 administration group at 25 and $50 \mu \mathrm{g} / \mathrm{mL}$, the secretion of IL-6 in BV-2 cells was significantly inhibited, indicating that MOS-Sia3 had a certain inhibitory effect on the inflammatory response induced by $\mathrm{A} \beta 42$ and that it can reduce the degree of cell damage caused by A $\beta 42$. The addition of MOS-Sia3 alone had little effect on the release of IL-6 in BV-2. In the presence of $100 \mu \mathrm{g} / \mathrm{mL}$ MOS-Sia3 and $A \beta 42$ (molar ratio of MOS-Sia3/A $\beta 42=1: 4.52$ ), the secretion of IL- 6 was close to that of the $A \beta 42$ model group. For TNF- $\alpha$ release, the trend was the same as that of IL-1 $\beta$ release. Compared with the blank group, the secretion of TNF- $\alpha$ in the A $\beta 42$ model group significantly increased, and secretion reached $854.2 \pm 3.2 \mathrm{pg} / \mathrm{mL}$ at $48 \mathrm{~h}$. The addition of MOS-Sia 3 at 25 and $50 \mu \mathrm{g} / \mathrm{mL}$ significantly inhibited the secretion of TNF- $\alpha$ in BV-2 cells, whereas a higher titer of $100 \mu \mathrm{g} / \mathrm{mL}$ MOS-Sia3 cannot inhibit IL-1 $\beta$ release.
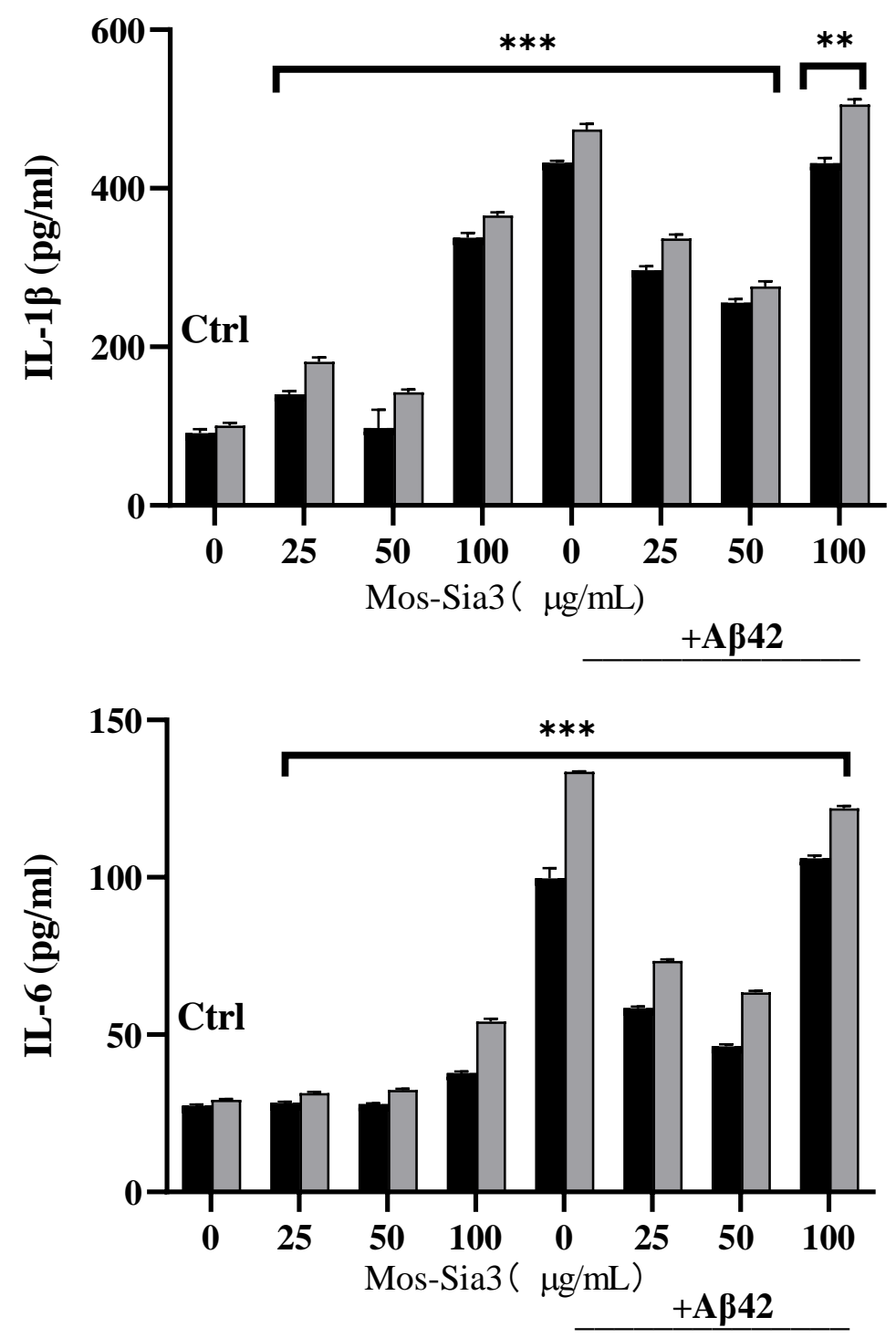

Figure 7. Effects of MOS-Sia3 on cytokine secretion in BV-2 cells induced by A $\beta 42$. Captions: Black bar, $24 \mathrm{~h}$ of culture; gray bar: $48 \mathrm{~h}$ of culture. Data are shown as the mean $\pm \mathrm{SD}$ of triplicates with good reproducibility. SD is represented as error bars. Statistically significant differences are indicated: ** for $p \leq 0.01$, and ${ }^{* * *}$ for $p \leq 0.001$. 


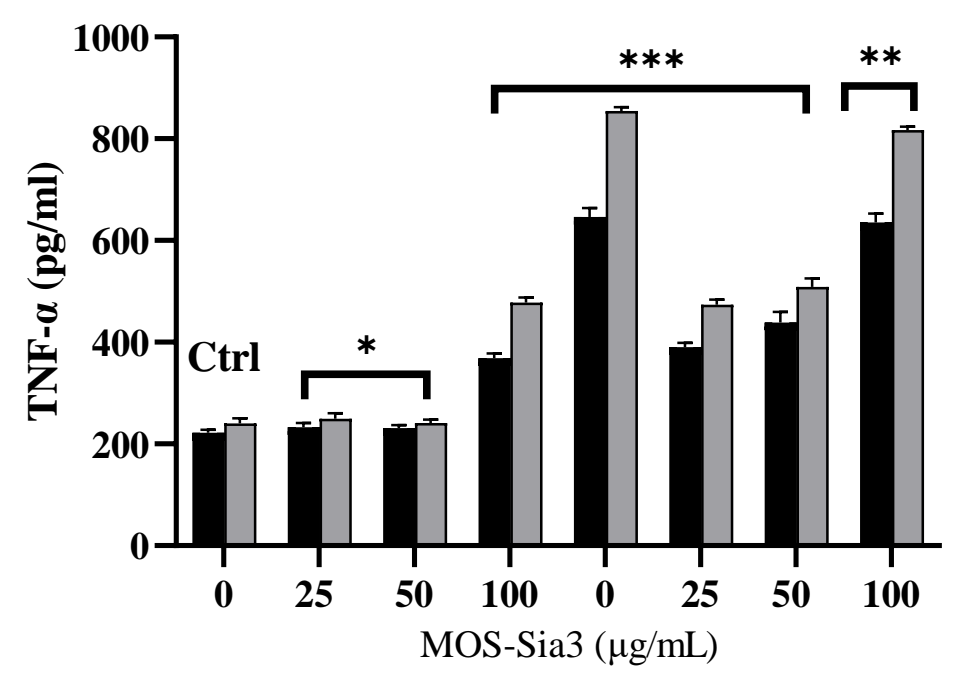

$+\mathrm{A} \beta 42$

Figure 8. Effects of MOS-Sia3 on cytokine secretion in BV-2 cells induced by A $\beta 42$. Captions: Black bar, $24 \mathrm{~h}$ of culture; gray bar: $48 \mathrm{~h}$ of culture. Data are shown as the mean $\pm \mathrm{SD}$ of triplicates with good reproducibility. SD is represented as error bars. Statistically significant differences are indicated: ** for $p \leq 0.01$, and ${ }^{* * *}$ for $p \leq 0.001$.

\section{Discussion}

Sialic acids play various roles in human physiology and pathophysiology. The highest levels of sialic acid are found in the brain, where they are expressed primarily in gangliosides and PSA (primarily in NCAM). PSA is an important regulator of neurogenesis that contributes to neuronal repair and recovery from neurodegeneration such as in AD [22]. However, in aged brains, the capacity of PSA regeneration is significantly reduced [23]. In order to overcome the structural instability of exogenous PSA, an oligosialic acid mimic with a relatively stable structure and negative charge was synthesized by using MOS and sialic acid monomer in this study. MOS-Sia3 can effectively inhibit the activation of BV-2 cells stimulated by $A \beta 42$ within a certain concentration range $(<50 \mu \mathrm{g} / \mathrm{mL})$ and keeps the cells in a normal physiological state. A higher concentration of MOS-Sia3 has the same effect of inhibiting cell-morphology changes, but it can inhibit the proliferation of BV-2 cells to a certain extent. When MOS-Sia3 is $>100 \mu \mathrm{g} / \mathrm{mL}$, it has a certain toxic effect on BV-2 and cannot inhibit the release of pro-inflammatory factors induced by $A \beta 42$, and it can even increase the secretion of IL- $1 \beta$ and TNF- $\alpha$. BV- 2 cells activated by A $\beta$ initially release IL-1 $\beta$ and TNF- $\alpha$, and then the cascade of TNF- $\alpha$ secretion damages neurons, further resulting in the release of IL- 6 . Among these pro-inflammatory factors, TNF- $\alpha$ can promote the deposition of $A \beta$, thereby reducing the ability of BV-2 cells to clear $A \beta$. As a result, an appropriate dose of MOS-Sia3 was selected in the present study when considering all nervous system cells.

Several functional oligosaccharides have been found to mitigate AD symptoms, especially those from food-derived antioxidant polysaccharides [24]. For instance, the lowmolecular-weight heparin can inhibit the transformation of $A \beta$ from random coil to $\beta$-sheet, among which the persulfated heparin tetrasaccharide is the best one [25]. A series of heparin oligosaccharide derivatives was designed and synthesized for the inhibition of $A \beta 40$ aggregation through molecular docking and molecular dynamics simulation [26]. Two $\mathrm{N}$-Acetyl chitooligosaccharides (pentasaccharides and tetrasaccharides) were synthesized and could improve the acquisition (learning) and retention (memory) of AD rats [27]. Furthermore, $\mathrm{k}$-carrageenan oligosaccharides were found to exert a good neuroprotective effect by inhibiting the inflammatory response of microglia [28]. Furthermore, selenized, phosphorylated, and terminal oxidized derivatives of MOS reportedly show antioxidation 
and anti-neuroinflammation effects [29,30]. Among them, the terminal oxidized derivative, GV-971, has been approved as a treatment for mild to moderate AD patients [14].

Microglial phagocytosis of $A \beta$ is an important function for protecting the brain from pathogenic invasion and for maintaining brain hemostasis. However, the balance between microglial activation and inflammation is disrupted in $\mathrm{AD}$, resulting in chronic neuroinflammation. A variety of Siglecs including CD33, Siglec-11, and Siglec-16 in human microglia can interact with sialic acid to allow microglia to return to an "off" sate [22]. Previous studies have shown that a biomimetic compound containing sialic acid structures similar to those expressed on neuronal membranes can compete and prevent cell-surface $\mathrm{A} \beta$ binding and associated cellular damage, thereby reducing the development of $A \beta$ pathology. For instance, a selenium nanoparticle modified with sialic acid and alternative B6 peptide conjugation (B6-Sia-SeNPs) has shown high blood-brain barrier permeability, as well as the abilities to inhibit $A \beta$ fibrillation and reduce $A \beta$ toxicity in a dose-dependent manner in PC12 and bEnd3 cells [31]. Additionally, a sialic-conjugated chitosan has been proven to inhibit A $\beta$-mediated toxicity in SH-SY5Y cells [32]. Our results proved that MOS-Sia3 can inhibit the aggregation and precipitation of $A \beta 42$, as well as the activation and release of pro-inflammatory factors in microglia within a certain dose. However, further research shall be conducted in $\mathrm{AD}$ animal models to test the $\mathrm{A} \beta$-toxicity reduction effect of MOS-Sia3.

\section{Materials and Methods}

\subsection{Materials}

N-Acetylneuraminicacid (Sia) was purchased from Chemstan Biotechnology Co., Ltd. (Wuhan, China). An ultrafiltration centrifuge tube ( $3 \mathrm{KDa}$ ) and dialysis tube were supplied by Solarbio Life Sciences (Beijing, China). A 342 was synthesized with NJPeptide (Nanjing, China). DMEM medium, fetal bovine serum, penicillin/streptomycin, and trypsin were supplied by Gibco Life Technologies (Grand Island, NY, USA). Methylthiazolyldiphenyl-tetrazolium bromide (MTT) was supplied by Lablead Biotechnology (Beijing, China). Other reagents were purchased from Sinopharm (Shanghai, China). Polymannuronic acid (PM; 3-5 KDa) was purchased from Qingdao BZ Oligo Biotech Co., Ltd. (Shandong, China)

\subsection{Preparation of $M O S$}

MOS was prepared by degradation assisted with microwave treatment. In a typical procedure, PM solution $(50 \mathrm{mg} / \mathrm{mL}, \mathrm{pH} 7-8)$ was treated at $120^{\circ} \mathrm{C}$ for $20 \mathrm{~min}$ (Multiwave PRO, Anton-Paar, Graz, Austria). After decolorization with activated carbon, filtration, precipitation with alcohol, centrifugation, rotary vacuum evaporation, and lyophilization of the hydrolysate, crude MOS were obtained. The crude MOS was redissolved in distilled water, precipitated multiple times with alcohol, and centrifuged, and then the supernatant was lyophilized. The obtained MOS was dissolved in water and subject to isolation with an ultrafiltration centrifuge tube $(3 \mathrm{KDa})$. The filtrate was discarded, and the retentate was collected and lyophilized to obtain the targeted MOS.

\subsection{Synthesis of MOS-Sia}

An appropriate amount of MOS $(30 \mathrm{mg} / \mathrm{mL})$ was dissolved in phosphate buffer ( $\mathrm{pH}$ 7.2). After reaction with ethylenediamine $(0.05 \mathrm{~mol} / \mathrm{L})$ and sodium cyanoborohydride $(0.1 \mathrm{~mol} / \mathrm{L})$ at $30^{\circ} \mathrm{C}$ for $36 \mathrm{~h}$, the reducing end of MOS was activated to obtain $\mathrm{MOS}-\mathrm{NH}_{2}$, which was dialyzed with a molecular-weight dialysis bag (500 Da), lyophilized, and stored in a $-20^{\circ} \mathrm{C}$ refrigerator.

\subsubsection{Synthesis of MOS-Sia by Reductive Amination}

In order to synthesize MOS-Sia, MOS- $\mathrm{NH}_{2}(30 \mathrm{mg} / \mathrm{mL})$ was reacted with $\mathrm{N}$-acetylneuraminic acid $(0.015 \mathrm{~mol} / \mathrm{L})$ and sodium cyanoborohydride $(0.15 \mathrm{~mol} / \mathrm{L})$ at $25^{\circ} \mathrm{C}$ for $36 \mathrm{~h}$ (Scheme 1$)$. The reaction solution was precipitated with five times the volume of ethanol, and the 
precipitate was dialyzed (500 Da) for $48 \mathrm{~h}$ in order to remove unreacted chemicals. The obtained product was rotary evaporated, lyophilized, and denoted as MOS-Sia1.

\subsubsection{Synthesis of MOS-Sia by Reductive Amidation}

In another method for MOS-Sia synthesis, MOS- $\mathrm{NH}_{2}(30 \mathrm{mg} / \mathrm{mL})$ was reacted with $\mathrm{N}$-acetylneuraminic acid $(5 \mathrm{mmol} / \mathrm{L})$ and EDC $(10 \mathrm{mmol} / \mathrm{L})$ at $25^{\circ} \mathrm{C}$ for $24 \mathrm{~h}$ (Scheme 1$)$. The reaction product was precipitated with an appropriate amount of acetone, and the precipitate was dissolved in distilled water again before dialyzing with a molecular-weight dialysis bag (500 Da; Solarbio Life Sciences). The obtained product was rotary evaporated, lyophilized, and denoted as MOS-Sia2.

\subsubsection{Synthesis of MOS-Sia by Thiol Condensation}

The reducing end of MOS was activated. In a typical procedure, MOS solution $\left(10 \mathrm{mg} / \mathrm{mL}\right.$, dissolved in PBS) was flushed with $\mathrm{N}_{2}$ for $10 \mathrm{~min}$ and reacted with mercaptoethylamine $(2.5 \mathrm{mg} / \mathrm{mL})$ at $25^{\circ} \mathrm{C}$ for $36 \mathrm{~h}$. The obtained product was rotary evaporated, dialyzed with a dialysis tube (500 Da, Solarbio Life Sciences), lyophilized, and denoted as MOS-SH.

According to Scheme 1, $\mathrm{N}$-acetylneuraminic acid was protected by methyl esterification and acetylation [33]. The obtained 1-Me-Ac ${ }_{5}$ SiaNAc was dissolved in dichloromethane and reacted with MOS-SH under the catalysis of boron trifluoride ether for $10 \mathrm{~h}$ in the presence of Amberlite IR120 resin (Merk, Darmstadt, Germany). The reaction product was rotary evaporated, dialyzed with a dialysis tube (1000 Da; Solarbio Life Sciences), lyophilized, and denoted as MOS-Sia3.

\subsection{Analytical Methods}

The modification rate of amino and sulfhydryl groups on oligosaccharides was determined by the trinitrobenzene sulfonic acid method [34] and the 2-nitrobenzoic acid method [35], respectively. MOS and its grafted products were measured by liquid-mass spectrometry (TSQ quantum Ultra EMR, Thermo Fisher Scientific, Waltham, MA, USA) and Fourier infrared spectroscopy (NEXUS 470, Thermo Nicolet, Waltham, MA, USA). Soluble $\mathrm{A} \beta$ was assayed using bicinchonininc acid method with a kit (Beyotime Biotechnology, Shanghai, China).

\subsection{Interaction of MOS-Sia with $A \beta 42$ and Metal Ions}

The interaction of MOS-Sia with metal ions and $A \beta 42$ was investigated according to the previous method with minor modification [36]. First, $50 \mu \mathrm{M}$ A $\beta 42$ solution (dissolved in $5 \mathrm{mM}$, pH 7.4 PBS) was incubated with MOS or MOS-Sia $(0.5 \mathrm{~g} / \mathrm{L})$ at $37^{\circ} \mathrm{C}$ for $24 \mathrm{~h}$. In another test, $5 \mathrm{mM}$ or $15 \mathrm{mM}$ of $\mathrm{CaCl}_{2}, \mathrm{CuCl}_{2}$, and $\mathrm{ZnCl}_{2}$ were mixed with $5 \mathrm{mM}$ of $\mathrm{A} \beta 42$, and then the mixtures were incubated with MOS or MOS-Sia $(0.5 \mathrm{~g} / \mathrm{L})$ at $37^{\circ} \mathrm{C}$ for $24 \mathrm{~h}$. All reaction solutions were measured with a circular dichrograph (MOS-450, BioLogic, Auvergne-Rhone-Alpes, Seyssinet-Parise, France) by using PBS as a control.

\subsection{Th-T Staining Analysis}

$\mathrm{A} \beta 42(10 \mathrm{mM})$ and MOS-Sia $(0.1 \mathrm{~g} / \mathrm{L})$ were dissolved in PBS (pH 7.4), incubated at $37^{\circ} \mathrm{C}$, and sampled every $8 \mathrm{~h}$. Then, $180 \mu \mathrm{L}$ of Th-T $(10 \mu \mathrm{M})$ was mixed with a $20 \mu \mathrm{L}$ sample in 96-well plates and determined with a microplate reader (MK3, Thermo Fisher Scientific, Waltham, MA, USA). The excitation and emission wavelengths were 450 and $485 \mathrm{~nm}$, respectively. The average fluorescence intensity of three tests of each sample was calculated. 


\subsection{Effect of MOS-Sia3 on the Cell Viability of BV-2 Cells and Cytokine Release Induced by A 342}

Culture of BV-2 cells (Langsheng Biotech Inc., Wuxi, China) was digested with $0.25 \%$ trypsin and centrifuged (1000 rpm, $5 \mathrm{~min})$. After counting with a hemocytometer, the cell concentration was adjusted and inoculated in a 96-well plate $(100 \mu \mathrm{L}, 5000$ cells/well). BV-2 cell culture was grouped as follows: (1) control (DMEM only); (2) A $\beta 42$ model group (added with $40 \mu \mathrm{g} / \mathrm{mL}$ A 342 ); (3) low MOS-Sia3 group (added with $25 \mu \mathrm{g} / \mathrm{mL}$ MOS-Sia3); (4) moderate MOS-Sia3 group (added with $50 \mu \mathrm{g} / \mathrm{mL}$ of MOS-Sia3); (5) high MOS- group (added with $100 \mu \mathrm{g} / \mathrm{mL}$ MOS-Sia3); (6) low MOS-Sia3 + Aß42 (added with $25 \mu \mathrm{g} / \mathrm{mL}$ MOS-Sia3 and $40 \mu \mathrm{g} / \mathrm{mL} A \beta 42$ ); (7) moderate MOS-Sia3 + A $\beta 42$ (added with $50 \mu \mathrm{g} / \mathrm{mL}$ MOS-Sia3 and $40 \mu \mathrm{g} / \mathrm{mL} \mathrm{A} \beta 42$ ); and (8) high MOS-Sia3 + A $\beta 42$ (added with $100 \mu \mathrm{g} / \mathrm{mL}$ MOS-Sia3 and $40 \mu \mathrm{g} / \mathrm{mL} \mathrm{A} \beta 42$ ).

The cells were cultivated for $24 \mathrm{~h}$ with DMEM. Then, the culture medium was decanted, and cells were cultivated with fresh DMEM supplemented with a certain concentration of $A \beta 42$ or $A \beta+M O S-S i a 3$ for another 24 or $48 \mathrm{~h}$. The culture with fresh DMEM served as a control. Afterwards, the culture was replaced with $90 \mu \mathrm{L}$ of fresh DMEM. Then, $10 \mu \mathrm{L}$ of MTT was added to each well, and the mixture was incubated for $3 \mathrm{~h}$ at $37^{\circ} \mathrm{C}$ in a $\mathrm{CO}_{2}$ incubator $(5 \%)$ in darkness. After aspirating the liquid in the wells, $200 \mu \mathrm{L}$ of DMSO was added, and the mixture was incubated for $10 \mathrm{~min}$ at room temperature in a shaker. The OD value was read with a microplate reader at $490 \mathrm{~nm}$ (MK3, Thermo Fisher Scientific, Waltham, MA, USA), and the average cytotoxicity was calculated from data of triplicate tests. Microscopy images of BV-2 cell were obtained with an optical microscope (Leica, Magdeburg, Germany). The supernatants of BV-2 cell culture after incubation for 24 or $48 \mathrm{~h}$ were collected by centrifugation (10 $\mathrm{min}, 3000 \mathrm{rpm})$ and subjected to cytokine assay through ELISA. IL-1 $\beta$ and TNF- $\alpha$ were measured using assay kits (MU30369/MU30030, Bioswamp, Wuhan, China). IL-6 was determined with an IL-6 assay kit (JL20268, Jianglaibio, Shanghai, China).

\subsection{Statistical Analysis}

Results are shown as the mean \pm standard deviation. Statistical comparison of means between and among groups was performed by using one-way ANOVA with the Student's $t$ test $(p \leq 0.05)$ and Tukey's Test using STATISTICA 13 (Dell, Tulsa, OK, USA).

\section{Conclusions}

Under mild conditions, three different MOS-Sia graft conjugates are successfully synthesized by linking with sialic acid monomer. The interaction between MOS-Sia and $\mathrm{A} \beta 42$ can reduce the $\beta$-structure formations of A $\beta 42$. MOS-Sia conjugates, especially MOS-Sia3, have a better complexing effect with $\mathrm{Ca}^{2+}$ while reducing the formation of A $\beta 42$ oligomers in solution. MOS-Sia3 can inhibit $70 \%$ of THT fluorescence intensity. A lower titer of MOS-Sia3 $(25-50 \mu \mathrm{g} / \mathrm{mL})$ can effectively inhibit the activation state of BV-2 cells stimulated by A $\beta 42$, whereas a higher dose of MOS-Sia3 $(>50 \mu \mathrm{g} / \mathrm{mL})$ can inhibit the proliferation of BV-2 cells to a certain extent. MOS-Sia3 can also inhibit the the expression of IL-1 $\beta$, IL-6, TNF- $\alpha$, and other proinflammatory factors in BV-2 cells induced by A $\beta 42$ activation, thereby reducing the damage and inflammation of BV-2 cells.

Author Contributions: Conceptualization, J.W.; methodology, M.W.; software, M.W.; validation, J.W., H.Z. and N.W.; formal analysis, H.Z.; investigation, J.W.; resources, N.W.; data curation, H.Z.; writing—original draft preparation, M.W.; writing—review and editing, J.W.; supervision, J.W.; project administration, X.Z.; funding acquisition, X.Z. All authors have read and agreed to the published version of the manuscript.

Funding: This research was funded by [the National Science and Technology Major Project] grant number [2018YFC1604105-5] And [the National First-Class Discipline Program of Light Industry Technology and Engineering] grant number [LITE2018-17]. 
Acknowledgments: This work was supported by the National Science and Technology Major Project (No. 2018YFC1604105-5) and the National First-Class Discipline Program of Light Industry Technology and Engineering (LITE2018-17).

Conflicts of Interest: There are no conflict to declare.

$\begin{array}{ll}\text { Abbreviations } \\ \text { ThT } & \text { Thioflavin T } \\ \text { AD } & \text { Alzheimer's disease } \\ \text { MOS } & \text { oligo mannuronic acid } \\ \text { Sia } & \text { sialic acid } \\ \text { PSA } & \text { polysialic acid } \\ \text { A } \beta & \text { Amyloid } \beta \\ \text { CD } & \text { circular dichroism } \\ \text { PBS } & \text { phosphate buffered saline } \\ \text { IL-1 } \beta & \text { interleukin-1 } \beta \\ \text { IL-6 } & \text { interleukin- } 6 \\ \text { TNF- } \alpha & \text { tumor necrosis factor- } \alpha\end{array}$

\section{References}

1. Sošić, M.; Vuletic, V.; Tomić, Z.; Bogdanovic, N. Diagnostic and therapeutic approach to a patient with cognitive impairment. Med. Flum. 2018, 54, 140-154. [CrossRef]

2. Cummings, J.; Lee, G.; Ritter, A.; Sabbagh, M.; Zhong, K. Alzheimer's disease drug development pipeline: 2019. Alzheimer's Dement. Transl. Res. Clin. Interv. 2019, 5, 272-293. [CrossRef] [PubMed]

3. Hukins, D.; MacLeod, U.; Boland, J.W. Identifying potentially inappropriate prescribing in older people with dementia: A systematic review. Eur. J. Clin. Pharmacol. 2019, 75, 467-481. [CrossRef]

4. Tagliavini, F.; Tiraboschi, P.; Federico, A. Alzheimer's disease: The controversial approval of Aducanumab. Neurol. Sci. 2021, 42, 3069-3070. [CrossRef] [PubMed]

5. Flynn, R.A.; Pedram, K.; Malaker, S.A.; Batista, P.J.; Smith, B.A.; Johnson, A.G.; George, B.M.; Majzoub, K.; Villalta, P.W.; Carette, J.E.; et al. Small RNAs are modified with N-glycans and displayed on the surface of living cells. Cell 2021, 184, 3109-3124.e22. [CrossRef]

6. Patel, D.A.; Henry, J.E.; Good, T.A. Attenuation of $\beta$-amyloid-induced toxicity by sialic-acid-conjugated dendrimers: Role of sialic acid attachment. Brain Res. 2007, 1161, 95-105. [CrossRef]

7. Cowan, C.B.; Coté, G.L.; Good, T.A. Development of photocrosslinked sialic acid containing polymers for use in amyloid beta toxicity attenuation. Biomaterials 2008, 29, 3408-3414. [CrossRef]

8. Griciuc, A.; Serrano-Pozo, A.; Parrado, A.R.; Lesinski, A.N.; Asselin, C.N.; Mullin, K.; Hooli, B.; Choi, S.H.; Hyman, B.T.; Tanzi, R.E. Alzheimer's Disease Risk Gene CD33 Inhibits Microglial Uptake of Amyloid Beta. Neuron 2013, 78, 631-643. [CrossRef]

9. Thiesler, H.; Beimdiek, J.; Hildebrandt, H. Polysialic acid and Siglec-E orchestrate negative feedback regulation of microglia activation. Cell. Mol. Life Sci. 2020, 78, 1637-1653. [CrossRef]

10. Hu, X.; Jiang, X.; Hwang, H.; Liu, S.; Guan, H. Antitumor activities of alginate-derived oligosaccharides and their sulphated substitution derivatives. Eur. J. Phycol. 2004, 39, 67-71. [CrossRef]

11. Yamamoto, Y.; Kurachi, M.; Yamaguchi, K.; Oda, T. Induction of Multiple Cytokine Secretion from RAW264.7 Cells by Alginate Oligosaccharides. Biosci. Biotechnol. Biochem. 2007, 71, 238-241. [CrossRef]

12. Fan, Y.; Hu, J.; Li, J.; Yang, Z.; Xin, X.; Wang, J.; Ding, J.; Geng, M. Effect of acidic oligosaccharide sugar chain on scopolamineinduced memory impairment in rats and its related mechanisms. Neurosci. Lett. 2005, 374, 222-226. [CrossRef]

13. Wang, X.J.; Chen, X.H.; Yang, X.Y.; Geng, M.Y.; Wang, L.M. Acidic oligosaccharide sugar chain, a marine-derived oligosaccharide, activates human glial cell line-derived neurotrophic factor signaling. Neurosci. Lett. 2017, 417, 176-180. [CrossRef]

14. Wang, X.; Sun, G.; Feng, T.; Zhang, J.; Huang, X.; Wang, T.; Xie, Z.; Chu, X.; Yang, J.; Wang, H.; et al. Sodium oligomannate therapeutically remodels gut microbiota and suppresses gut bacterial amino acids-shaped neuroinflammation to inhibit Alzheimer's disease progression. Cell Res. 2019, 29, 787-803. [CrossRef]

15. Salloway, S.; Sperling, R.; Keren, R.; Porsteinsson, A.; Van Dyck, C.H.; Tariot, P.N.; Gilman, S.; Arnold, D.; Abushakra, S.; Hernandez, C.; et al. A phase 2 randomized trial of ELND005, scyllo-inositol, in mild to moderate Alzheimer disease. Neurology 2011, 77, 1253-1262. [CrossRef] [PubMed]

16. Stark, T.; Lieblein, T.; Pohland, M.; Kalden, E.; Freund, P.; Zangl, R.; Grewal, R.; Heilemann, M.; Eckert, G.P.; Morgner, N.; et al. Peptidomimetics That Inhibit and Partially Reverse the Aggregation of A $\beta 1-42$. Biochemistry 2017, 56, 4840-4849. [CrossRef]

17. Xu, P.; Zhang, M.; Sheng, R.; Ma, Y. Synthesis and biological evaluation of deferiprone-resveratrol hybrids as antioxidants, $\mathrm{A} \beta$ 1-42 aggregation inhibitors and metal-chelating agents for Alzheimer's disease. Eur. J. Med. Chem. 2017, 127, 174-186. [CrossRef] 
18. Krishnan, H.S.; Bernard-Gauthier, V.; Placzek, M.S.; Dahl, K.; Narayanaswami, V.; Livni, E.; Chen, Z.; Yang, J.; Collier, T.L.; Ran, C.; et al. Metal Protein-Attenuating Compound for PET Neuroimaging: Synthesis and Preclinical Evaluation of [ ${ }^{11}$ C]PBT2. Mol. Pharm. 2018, 15, 695-702. [CrossRef] [PubMed]

19. Murthy, R.V.; Bharate, P.; Gade, M.; Sangabathuni, S.; Kikkeri, R. Effect of Transition Metals on Polysialic Acid Structure and Functions. ChemMedChem 2016, 11, 667-673. [CrossRef] [PubMed]

20. Younan, N.D.; Viles, J.H. A Comparison of Three Fluorophores for the Detection of Amyloid Fibers and Prefibrillar Oligomeric Assemblies. ThT (Thioflavin T); ANS (1-Anilinonaphthalene-8-sulfonic Acid); and bisANS (4,4'-Dianilino-1,1'-binaphthyl-5,5'disulfonic Acid). Biochemistry 2015, 54, 4297-4306. [CrossRef] [PubMed]

21. Fang, M.; Zhao, Y.; Liu, X. High A $\beta$ load may cause microglial cell dysfunction and reduced nuclear repressor element-1 silencing transcription factor (REST) expression which might be ascribed to its degradation by ubiquitination. Ann. Transl. Med. 2019, 7, 338. [CrossRef]

22. Rawal, P.; Zhao, L. Sialometabolism in Brain Health and Alzheimer's Disease. Front. Neurosci. 2021, 15, 308. [CrossRef]

23. Schnaar, R.L.; Gerardy-Schahn, R.; Hildebrandt, H. Sialic Acids in the Brain: Gangliosides and Polysialic Acid in Nervous System Development, Stability, Disease, and Regeneration. Physiol. Rev. 2014, 94, 461-518. [CrossRef]

24. Li, H.; Ding, F.; Xiao, L.; Shi, R.; Wang, H.; Han, W.; Huang, Z. Food-Derived Antioxidant Polysaccharides and Their Pharmacological Potential in Neurodegenerative Diseases. Nutrients 2017, 9, 778. [CrossRef] [PubMed]

25. Zhou, X.; Jin, L. The Structure-Activity Relationship of Glycosaminoglycans and Their Analogues with $\beta$-Amyloid Peptide. Protein Pept. Lett. 2016, 23, 358-364. [CrossRef] [PubMed]

26. Paul, T.; Kelly, H.; Zuchniarz, J.; Ahmed, T.; Prabhakar, R. Design of heparin oligosaccharide based molecules for inhibition of Alzheimer amyloid beta (A $\beta 40)$ aggregation. Can. J. Chem. 2016, 94, 1090-1098. [CrossRef]

27. Jiang, Z.; Liu, G.; Yang, Y.; Shao, K.; Wang, Y.; Liu, W.; Han, B. N-Acetyl chitooligosaccharides attenuate amyloid $\beta$-induced damage in animal and cell models of Alzheimer's disease. Process. Biochem. 2019, 84, 161-171. [CrossRef]

28. Ai, L.; Chung, Y.-C.; Lin, S.-Y.; Jeng, K.-C.G.; Lai, P.F.-H.; Xiong, Z.-Q.; Wang, G. Carrageenan polysaccharides and oligosaccharides with distinct immunomodulatory activities in murine microglia BV-2 cells. Int. J. Biol. Macromol. 2018, 120, 633-640. [CrossRef]

29. Zhu, Z.; Liu, Q.; Chen, P.; Xu, X.; Ni, J.; Yang, S.; Song, Y. Seleno-polymannuronate synthesis and resistance to oxidation and apoptosis in Alzheimer's disease cells. Chem. J. Chin. Univ. 2013, 34, 115-122.

30. Li, Q.; Zeng, Y.; Wang, L.; Guan, H.; Li, C.; Zhang, L. The heparin-like activities of negatively charged derivatives of lowmolecular-weight polymannuronate and polyguluronate. Carbohydr. Polym. 2016, 155, 313-320. [CrossRef]

31. Yin, T.; Yang, L.; Liu, Y.; Zhou, X.; Sun, J.; Liu, J. Sialic acid (SA)-modified selenium nanoparticles coated with a high blood-brain barrier permeability peptide-B6 peptide for potential use in Alzheimer's disease. Acta Biomater. 2015, 25, 172-183. [CrossRef]

32. Dhavale, D.D. Sialic Acid Conjugated Chitosan for the Attenuation of Amyloid-Beta Toxicity. Master's Thesis, Louisiana State University, Baton Rouge, LA, USA, 2009.

33. Li, J.; Zhang, J.; Zhang, Q.; Bai, Z.; Zhao, Q.; He, D.; Wang, Z.; Chen, Y.; Liu, B. Syntheses and anti-cancer activity of CO-releasing molecules with targeting galactose receptors. Org. Biomol. Chem. 2018, 16, 8115-8129. [CrossRef] [PubMed]

34. Hanh, V.T.; Kobayashi, Y.; Maebuchi, M.; Nakamori, T.; Tanaka, M.; Matsui, T. Quantitative mass spectrometric analysis of dipeptides in protein hydrolysate by a TNBS derivatization-aided standard addition method. Food Chem. 2016, 190, 345-350. [CrossRef] [PubMed]

35. Ellman, G.L.; Courtney, K.D., Jr.; Andres, V.; Featherstone, R.M. A new and rapid colorimetric determination of acetylcholinesterase activity. Biochem. Pharmacol. 1961, 7, 88-90. [CrossRef]

36. Lei, Y.; Wu, M.; Wang, J.; Zhang, H.; Zhan, X.; Sun, Z.; Wu, J. Preparation and property of a biantenna macromolecule based on polysialic acid. Int. J. Biol. Macromol. 2019, 155, 1342-1349. [CrossRef] [PubMed] 